\title{
TAXONOMIC AND EVOLUTIONARY SIGNIFICANCE \\ OF BIOGENIC AMINES AND POLYPEPTIDES \\ IN AMPHIBIAN SKIN. II. TOADS OF THE \\ GENERA BUFO AND MELANOPHRYNISCUS
}

\author{
COLECCION HERPETOLOGICA \\ Y BIBLIOTECA \\ Dr. José Miguel Cei \\ BIBLIOTECA \\ JCRGE D. WILLIAMS
}

J. M. Cer, V. Erspamer and M. Roseghini

Reprinted from Systematic Zoology

Vol. 17, No. 3, September 1968

pp. 232-245

Made in United States of America 


\title{
TAXONOMIC AND EVOLUTIONARY SIGNIFICANCE OF BIOGENIC AMINES AND POLYPEPTIDES IN AMPHIBIAN SKIN. II. TOADS OF THE GENERA BUFO AND MELANOPHRYNISCUS
}

\author{
J. M. Cei, V. Enspamer and M. Roseghini
}

The value of the study of biogenic amines and active polypeptides of the amphibian skin in providing taxonomic evidence has been pointed in an earlier paper (Cei, Erspamer and Roseghini, 1967). The point was stressed that biochemical taxonomy, in its broadest sense, is possibly more discriminating than traditional taxonomy, based on somatic or osteological structures, size or coloration. In the first paper of this series sets of biochemical and pharmacological data concerning the skins of leptodactylid frogs were reported and discussed. The present paper deals similarly with representatives of another very important family of Procoela, the Bufonidae.

The Bufonidae display in their skin, besides many steroid derivatives (bufotoxins and bufagins), a formidable array of indolealkylamines. Several of them derive their name from Bufo: bufotenine, bufotenidine, bufoviridine, dehydrobufotenine and bufothionine. In addition to indolealkylamines, phenylalkylamines also may be occasionally present. Imidazolealkylamines may occur only in trace amounts, and probably are of no particular significance. Similarly, the skin in the Bufonidae apparently lacks polypeptides, active on plain muscle and/or external secretions, such as physalaemin, bradykinin, and caerulein-like polypeptides.

Paper chromatographic analysis has been already used by some authors (Hunsaker, Alston, Blair and Turner, 1961; Wittliff, 1962; Porter, 1962, 1964) in the study of parotoid gland secretion, with the aim of assessing intragroup and intergroup relationships. However, the limited number of examined species has hitherto prevented a broad application of this kind of evidence to the general problems of phyletic relationships in the genus Bufo.

Analysis of our biochemical data was carried out having in mind the classical osteological data by Tihen (1962) and other recent reports on evolution and taxonomy of amphibians, among which is the report by Blair (1963) on the origin and evolutionary deployment of the actual species of toads, especially of the different lines of the genus Bufo occurring now in North America.

\section{MATERIALS AND METHODS}

The species considered in this paper, together with data concerning number and state of the skins, date and place of collection are indicated in the tables. Only the genera Melanophryniscus from South America, and Bufo from several localities of Eurasia, Africa and America were studied. In all, 48 species and subspecies were checked.

Acetone was the solvent routinely used for the extraction of the skins. In fact, $80 \%$ acetone is the most suitable solvent for a complete recovery of tissue indolealkylamines. In the case of suspected occurrence of histamines or of polypeptides, methanol extraction was used in parallel.

For details on the simple extraction procedure and for the description of paper chromatographic and biological methods we refer to other papers (Erspamer, Roseghini and Cei, 1964; Erspamer, Vitali, Roseghini and Cei, 1964, 1967).

The problem of whether the amine spectrum found in dried skins may be considered qualitatively and quantitatively comparable with that occurring in fresh skins has been discussed in the first paper of this 
TABLE 1. The CONTENT OF INDOLEALKYLAMINES IN THE SKIN OF TOADS (IN $\mu$ G FREE BASES PER G TISSUE).?

\begin{tabular}{|c|c|c|c|c|c|c|c|}
\hline $\begin{array}{l}\text { Taxa, sample size, } \\
\text { locality, date }\end{array}$ & 5-HT & $\begin{array}{l}\text { N-Methyl- } \\
\text { 5-HT }\end{array}$ & Bufotenine & Bufotenidine & $\begin{array}{l}\text { Dehydro- } \\
\text { bufotenine }\end{array}$ & Bufothionine & Bufoviridine \\
\hline \multicolumn{8}{|l|}{ "African line" } \\
\hline $\begin{array}{l}\text { B. mauretanicus } \\
\text { (15:pool) Morocco, } \\
1952 \text { (F) } \\
\text { (5:pool) Morocco, }\end{array}$ & 310 & 0 & 0 & 0 & 0 & 0 & 0 \\
\hline B. regularis & $480-500$ & 0 & 0 & 0 & 0 & 0 & 0 \\
\hline (220:pool) Congo, 1957 & 540 & 0 & 0 & 0 & 0 & 0 & 0 \\
\hline & 2500 & 0 & 0 & 0 & 0 & 0 & 0 \\
\hline $\begin{array}{l}\text { (pool) Congo, } 1952 \\
\text { B. berghei }\end{array}$ & 600 & 0 & 0 & 0 & 0 & 0 & 0 \\
\hline $\begin{array}{l}\text { (pool) Congo, } 1952 \\
B, \text { funereus }\end{array}$ & 150 & 0 & 0 & 0 & 0 & 0 & 0 \\
\hline (129:pool) Congo, 1957 & 180 & 0 & 0 & $\mathbf{0}$ & 0 & 0 & 0 \\
\hline \multicolumn{8}{|l|}{ "South-Oriental line" } \\
\hline $\begin{array}{l}\text { B. melanostictus } \\
\text { (100:pools) Malaya, Kuala } \\
\quad \text { Lumpur, 1964,6 }\end{array}$ & 130 & 0 & $17-20$ & 1250 & $8-9$ & 0 & 0 \\
\hline \multicolumn{8}{|l|}{ "Paleartic line" } \\
\hline $\begin{array}{l}\text { B. bufo bufo } \\
\text { (15) Italy, Parma, } \\
\text { 1966, } 4 \text { (F) } \\
\text { (7:pool) Italy, Bologna, }\end{array}$ & $\begin{array}{c}\text { traces } \\
(0-13)\end{array}$ & 0 & $\begin{array}{c}169 \pm 24 \\
(45-400)\end{array}$ & $\begin{array}{c}54 \pm 10 \\
(5-150)\end{array}$ & $\begin{array}{c}98 \pm 11 \\
(30-175)\end{array}$ & $\begin{array}{c}320 \pm 33 \\
(90-750)\end{array}$ & 0 \\
\hline & 20 & 0 & 450 & 50 & 130 & 320 & 0 \\
\hline (9:pool) Japan, 1962 & 65 & 60 & 150 & 140 & 25 & 375 & 0 \\
\hline calamita group & & & & & & & \\
\hline $\begin{array}{l}\text { B. viridis } \\
\text { (150:pool) Italy, Parma, } \\
1959,4 \text { (F) } \\
\text { (20:pool) Italy, Bologna, }\end{array}$ & $5-10$ & $20-25$ & 650 & 30 & 0 & 0 & 480 \\
\hline $\begin{array}{l}1964,4(F) \\
\text { (12:pool) Italy, Tuscany, }\end{array}$ & 10 & $?$ & 750 & 50 & 0 & 0 & 110 \\
\hline $\begin{array}{l}\text { 1967, } 4(\mathrm{~F}) \\
\text { B. calamita } \\
\text { (pool) Central Europe, } \\
1954(\mathrm{~F})\end{array}$ & $6-8$ & $13-15$ & 1500 & 100 & 7 & 5 & 300 \\
\hline
\end{tabular}

10 , not detectable $(<1-2 \mu \mathrm{g} / \mathrm{g})$; $(\mathrm{F})$, fresh skin. Toads of the regulus stock contain, in addition to $5-\mathrm{HT}$, the $O$. sulphate of 5-HT and another more complex conjugate of 5-HT.

series (Cei, Erspamer and Roseghini, 1967) and will be discussed in detail in other papers.

\section{RESULTS}

Results of paper chromatographic and biological screening are presented in Tables 1 to 6 . The species examined were tentatively arranged having in mind the general conclusions of the Blair's report (1963) and some personal assumptions.

The tables indicate, for each species, number of specimens (noting whether screening has been carried out on pooled skins or on single specimens) and locality, year, and month of collection. In the tables, both average values obtained from pooled skins and values obtained from single individuals are reported. Average and standard error have been calculated, and the range of values is shown in parentheses. Unless otherwise stated, dried skins were examined and acetone was used for extraction. Fresh skins were indicated with (F), and eventual methanol extraction with (MET).

5 -Hydroxyindoleacetic acid is a rather common constituent of extracts of the skin of a number of toads. Although its occurrence in small amounts in the living skin is highly probable, as shown by its presence in extracts prepared from fresh skin, the 
TABLE 2. THE CONTENT OF INDOLEALKYLAMines OF THE SKIN OF TOADS (IN $\mu$ G FREE BASES PER G SKIN). ${ }^{1}$

\begin{tabular}{|c|c|c|c|c|c|c|c|}
\hline $\begin{array}{c}\text { Taxa, sample size, } \\
\text { locality, date }\end{array}$ & 5-HT & $\begin{array}{c}\text { N-Methyl- } \\
\text { 5-HT }\end{array}$ & Bufotenine & Bufotenidine & $\begin{array}{l}\text { Dehydro- } \\
\text { bufotenine }\end{array}$ & Bufothionine & $\begin{array}{c}\begin{array}{c}\text { Other } \\
\text { conjugates }\end{array} \\
\end{array}$ \\
\hline \multicolumn{8}{|l|}{ "North-Western line" } \\
\hline \multicolumn{8}{|l|}{ boreas group } \\
\hline \multicolumn{6}{|l|}{$\begin{array}{l}\text { B. boreas boreas } \\
\text { (14) USA, Wyoming, } \\
\text { Medicine Bow Mt., }\end{array}$} & $\begin{array}{l}67.5 \pm 9.3 \\
(20-120)\end{array}$ & 0 \\
\hline $\begin{array}{l}\text { (4) USA, Colorado, } \\
\text { Cameron Pass, 1964, } 7\end{array}$ & - & 0 & $\begin{array}{c}1465 \pm 139 \\
(260-2500)\end{array}$ & $\begin{array}{l}72.5 \pm 7 \\
(20-130)\end{array}$ & 0 & $\begin{array}{l}492.5 \pm 13 \\
(360-570)\end{array}$ & 0 \\
\hline $\begin{array}{l}\text { B. boreas halophilus } \\
\text { (1) USA, California, } \\
\text { Riverside, 1963, } 9\end{array}$ & 0 & 0 & 275 & 50 & 0 & 275 & $\mathbf{0}$ \\
\hline \multicolumn{8}{|l|}{ alvarius group (see TABLE 3) } \\
\hline \multicolumn{8}{|l|}{ punctatus group } \\
\hline $\begin{array}{l}\text { B. punctatus } \\
\text { (6) USA, Arizona, } \\
\text { Mesa, 1964, } 8\end{array}$ & 0 & 0 & $\begin{array}{l}10-20 \text { in } \\
\text { three speci- } \\
\text { mens only }\end{array}$ & $\begin{array}{l}0 \\
0\end{array}$ & $\begin{array}{c}543 \pm 136 \\
(125-1000)\end{array}$ & $\begin{array}{c}465 \pm 109 \\
(100-750)\end{array}$ & $?$ \\
\hline \multirow{4}{*}{$\begin{array}{l}\text { (3:pool) USA, Arizona, } \\
\text { Tucson, 1964, 10 } \\
\text { (1) USA, Arizona, } \\
\text { Portal, 1965, 7 } \\
\text { (2:pool) USA, California, } \\
\text { Palm Desert, 1965, } 7 \\
\text { (8:pool) Mexico, Telaja, } \\
\text { 1966, 7 } \\
\text { B. marmoreus }\end{array}$} & 0 & 0 & 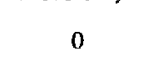 & 0 & 500 & 400 & 60 \\
\hline & 0 & 0 & 50 & 0 & 900 & 600 & 5 \\
\hline & 0 & 0 & 10 & 0 & 500 & 1200 & 570 \\
\hline & 0 & 0 & 20 & 0 & 1750 & 4000 & 3000 \\
\hline \multirow{3}{*}{$\begin{array}{l}\text { (4:pool) Mexico, Guerrero, } \\
\text { 1964, } 9 \\
\text { B. perplexus } \\
\text { (9:pool) Mexico, Puebla, } \\
\text { 1965, } 7 \\
\text { (6:pool) Mexico, Puebla, } \\
\text { 1966, } 7\end{array}$} & 150 & 0 & 770 & 0 & 0 & 0 & $850^{2}$ \\
\hline & 140 & 0 & 1400 & 0 & 0 & 0 & $\begin{array}{l}10 \\
1700^{2} \\
6\end{array}$ \\
\hline & 150 & 0 & 2400 & 0 & 0 & 0 & $500^{2}$ \\
\hline \multicolumn{8}{|l|}{ debilis group } \\
\hline $\begin{array}{l}\text { B. debilis } \\
\text { (9) USA, Texas, } \\
\text { Valentine, 1965, } 7\end{array}$ & 0 & $\begin{array}{l}50-75 \text { in } \\
\text { four speci- } \\
\text { mens only }\end{array}$ & $\begin{array}{l}\text { I5-64 in } \\
\text { four speci- } \\
\text { mens only }\end{array}$ & 0 & $\begin{array}{c}1745 \pm 368 \\
(550-3600)\end{array}$ & $\begin{array}{c}802 \pm 167 \\
(390-1700)\end{array}$ & $\begin{array}{l}20-250 \\
\text { in five } \\
\text { specimens }\end{array}$ \\
\hline
\end{tabular}

larger amounts sometimes found in extracts of dried skins may be interpreted as originating post mortem from the oxidative deamination of 5-hydroxyindolealkylamines, especially 5-HT and N-methyl-5-HT. However, the significance of 5-hydroxyindoleacetic and of other more rare metabolites (5-hydroxytryptophol, 5-methoxyindoleacetic acid, 5-methoxytryptophol), similarly arising from oxidative deamination of indolealkylamines, is negligible in the present study.

Other indole derivatives are occasionally detectable on paper chromatograms of skin extracts. Several of them, for example, regularly occurs on chromatograms of extracts of Bufo mauritanicus, Bufo regularis, and other toads of the "African line." The identification of these derivatives is necessary before any inference can be made about their possible value in the distinction of species groups.

Compounds of probable phenolic nature, possibly phenylalkylamines or phenolic acids, are present in several skin extracts of toads and may be taxonomically interesting. However, none of these phenolic compounds has been so far identified, and for 
Table 3. The content of Bufotenine and O-Methylbufotenine in the sKin OF Bufo alvarius (IN MG/G SKIN). ${ }^{1}$

\begin{tabular}{lccccc}
\hline & \multicolumn{2}{c}{ Bufotenine } & & \multicolumn{2}{c}{ O-Methylbufotenine } \\
\cline { 2 - 3 } \cline { 5 - 6 } Sample & Glands & Remaining skin & & Glands & Remaining skin \\
\hline (1) USA, Arizona, Tucson, 1963, 11 & 2.2 & 1.5 & 80 & 3.2 \\
(2) USA, Arizona, Mesa, 1964, 5 & $0.9,1.1$ & $0.33,2.1$ & & 100,160 & $1.2,3.0$ \\
(9) USA, Arizona, Mesa, 1964, & $2.3 \pm 0.50$ & $1.07 \pm 0.19$ & & $98 \pm 11$ & $2.0 \pm 0.2$ \\
& $(0.9-5)$ & $(0.8-2.2)$ & & $(60-160)$ & $(1.0-3.5)$ \\
(4) USA, Arizona, Mesa, 1965, & $0.3-0.5$ & $1.25-5.5$ & & $107-146$ & $2.0-3.9$ \\
(1) USA, California, 1965,7 & 0.1 & 0.17 & & & 0.6 \\
(3) USA, Arizona, Mesa, 1966, 8 & 0.1 & $0.5-0.9$ & & $77-107$ & $0.4-0.7$ \\
\hline
\end{tabular}

1 Large cutaneous glands (coxal and parotoid glands) and the remaining skin were separately investigated.

In the pools of the 9 non-glandular skins collected in Arizona during August 1964, the following additional indolealkylamines were detected (in $\mu$ g per g dry skin) : 5-HT 4-6, $N$-methyl-5-HT 30-40, $N$-methyl-5-methoxytryptamine 10-15, bufoviridine 15-20, $O$-sulphate of bufotenine 80-90, and $O$-methylbufotenine I-sulphonic acid 90-100 (cf. Erspamer, Vitali, Roseghini and Cei, 1967).

this reason they have not been considered here.

With the exception of histidine and $N$ acetylhistidine (Erspamer, Roseghini and Anastasi, 1965), no known imidazole derivatives were traced on chromatograms of skin extracts of bufonids.

As previously stated, active polypeptides do not seem to occur, at least in important amounts, in the skin of bufonids. Hence, neither of these compounds contributes to understand taxonomic problems in the Bufonidae.

\section{DISCUSSION}

\section{I}

Indolealkylamines found in the skin of the bufonids examined in the present study were as follows:

5-hydroxytryptamine (5-HT), $\mathrm{N}$-methyl-5HT, bufotenine, bufotenidine, bufoviridine (bufotenine 1-sulphonic acid), bufotenine $O$-sulphate, dehydrobufotenine, bufothionine (dehydrobufotenine $\mathrm{O}$-sulphate) $\mathrm{N}$ methyl-5-methoxytryptamine, $O$-methylbufotenine $\quad(N, N$-dimethyl-5-methoxytryptamine), $O$-methylbufotenine 1 -sulphonic acid.

5-Hydroxyindoleacetic acid, 5-hydroxytryptophol, 5-methoxyindoleacetic acid and 5 -methoxytryptophol were current or occasional metabolites of 5-hydroxy- and 5methoxyindolealkylamines, respectively.

As already stated, known imidazolealkylamines and phenylalkylamines were not present in important amounts. The same is true for polypeptides active on plain muscle and/or external secretions.

The occurrence of such a very rich assortment of indolealkylamines requires the activity of the following enzyme systems: tryptophan 5-hydroxylase, the enzyme responsible for the 5-hydroxylation of tryptophan, i.e., responsible for the biosynthesis of 5-hydroxytryptophan, the obligatory precursor of all 5-hydroxy- and 5-methoxyindolealkylamines; decarboxylase of aromatic L-aminoacids (5-hydroxytryptophan decarboxylase), capable of decarboxylating 5hydroxytryptophan to $5-\mathrm{HT} ; \mathrm{N}$-methyl transferase, responsible for the transformation of the primary into the secondary and tertiary amine, and then into the quaternary ammonium base; 5-hydroxyindole-O-methyl transferase, causing a methylation of the hydroxy group of the nucleus and giving thus origin to 5-methoxyindoles; a dehydrogenase, possibly involved in the biosynthesis of dehydrobufotenine, proceeding by dehydrogenation of bufotenine to a paraquinonid structure which then cyclises by nucleophilic addition of the $-\mathrm{H}\left(\mathrm{CH}_{3}\right)_{2}$ group (Robinson et al., 1961); finally one or two sulphoconjugases, capable of linking sulphuric acid to the phenolic hydroxy group ( $O$-sulphoconjugase) or to the pyrrolic NH group (1-sulphoconjugase ?).

For the present, the existence of a 1sulphoconjugase as an enzyme distinct from $O$-sulphoconjugase is questionable. 


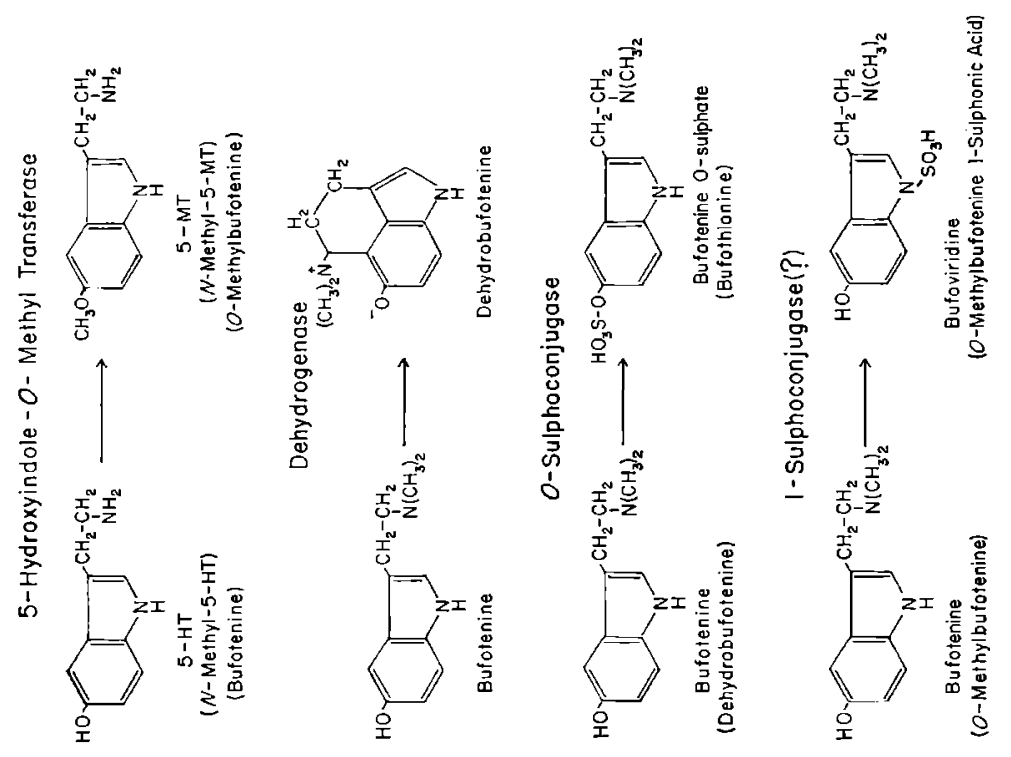

落

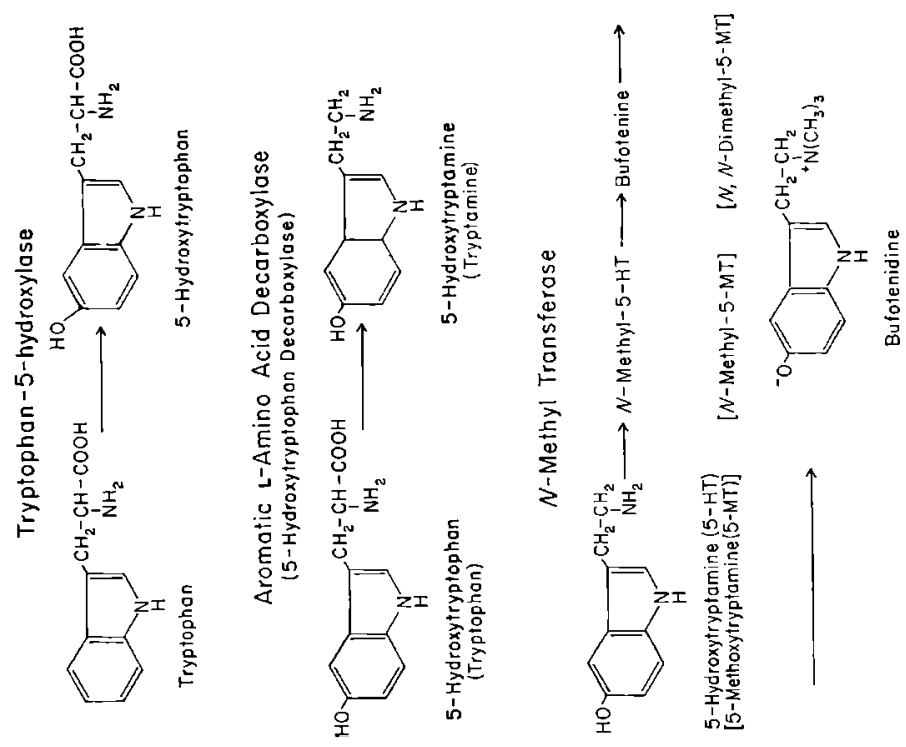


Table 4. The CONTENT OF INDOLEalkylamines OF THE SKIN OF TOADS (IN $\mu$ G FREE BASES PER G TISSUE). ${ }^{1}$

\begin{tabular}{|c|c|c|c|c|c|c|c|}
\hline $\begin{array}{l}\text { Taxa, sample size, } \\
\text { locality, date }\end{array}$ & 5-HT & $\begin{array}{l}\text { N-Methyl- } \\
\mathbf{5} \text {-HT }\end{array}$ & Bufotenine & Bufotenidine & $\begin{array}{l}\text { Dehydro- } \\
\text { bufotenine }\end{array}$ & Bufothionine & $\begin{array}{l}\text { Bufotenine } \\
O \text {-sulphate }\end{array}$ \\
\hline \multicolumn{8}{|l|}{$\begin{array}{l}\text { "South-Western line" } \\
\text { spinulosus group }\end{array}$} \\
\hline $\begin{array}{l}\text { B. spinulosus limensis } \\
\text { (7) Perú, Trujillo, 1965, } 1\end{array}$ & 0 & 0 & $\begin{array}{c}111+36 \\
(25-300)\end{array}$ & $\begin{array}{l}350 \pm 102 \\
(65-800)\end{array}$ & $\begin{array}{c}463 \pm 34 \\
(320-560)\end{array}$ & $\begin{array}{c}720 \pm 111 \\
(300-1200)\end{array}$ & 0 \\
\hline $\begin{array}{l}\text { B. spinulosus } \\
\text { (7) Perú, Cajarnarca, } \\
2800 \text { mtr., 1965, } 1\end{array}$ & 0 & 0 & $\begin{array}{l}127 \pm 27 \\
(60-250)\end{array}$ & $\begin{array}{c}211 \pm 52 \\
(80-400)\end{array}$ & $\begin{array}{l}1835 \pm 319 \\
(950-3000)\end{array}$ & $\begin{array}{c}2100 \div 322 \\
(940-3750)\end{array}$ & 0 \\
\hline $\begin{array}{l}\text { B. spinulosus spinulosus } \\
\text { (18:pools) Perú, Cuzco, } \\
3500 \text { mtr., 1963, } 1\end{array}$ & 0 & 0 & 230 & 30 & 180 & $940-1100$ & 0 \\
\hline $\begin{array}{l}\text { B. spinulosus } \\
\text { (6) Chile, Atacama, S. Pedro, } \\
2500 \text { mtr., 1965, } 10\end{array}$ & , & 0 & $\begin{array}{c}785 \pm 264 \\
(400-2000)\end{array}$ & $\begin{array}{c}61 \pm 7 \\
(40-80)\end{array}$ & $\begin{array}{c}536 \pm 275 \\
(150-1900)\end{array}$ & $\begin{array}{l}2200 \pm 440 \\
(500-4400)\end{array}$ & 0 \\
\hline $\begin{array}{l}\text { B. spinulosus chilensis } \\
\text { (15:pool) Chile, Valparaíso, } \\
\text { 1966, 1 } \\
\text { (8:pool) Chile, Zapallar, } \\
1966,1\end{array}$ & 0 & 0 & 250 & 45 & 1000 & 1000 & 270 \\
\hline $\begin{array}{l}\text { B. spinulosus } \\
\text { (9) Argentina, Mendoza, } \\
\text { Sosneado, 1965, } 3\end{array}$ & $\begin{array}{l}\text { scarce } \\
20-150 \text { in } \\
v \text { specimens }\end{array}$ & 0 & $\begin{array}{c}134 \pm 31 \\
(20-320)\end{array}$ & $\begin{array}{c}33 \pm 4 \\
(25-60)\end{array}$ & $\begin{array}{c}929 \pm 172 \\
(360-2200)\end{array}$ & $\begin{array}{c}840 \pm 128 \\
(375-1850)\end{array}$ & 0 \\
\hline $\begin{array}{l}\text { (6) Argentina, Mendoza, } \\
\text { Malargüe, 1965, } 3\end{array}$ & $\begin{array}{l}\text { scarce } \\
\text { ( } 10-40 \text { in } \\
\text { specimens })\end{array}$ & 0 & $\begin{array}{c}71 \pm 16 \\
(20-120)\end{array}$ & $\begin{array}{c}26 \pm 9 \\
(10-70)\end{array}$ & $\begin{array}{c}850 \pm 160 \\
(400-1500)\end{array}$ & $\begin{array}{l}360 \pm 109 \\
(90-950)\end{array}$ & 0 \\
\hline $\begin{array}{l}\text { (6) Argentina, Mendoza, } \\
\text { Mina Huemul, 1964, } 3\end{array}$ & $\begin{array}{l}22 \pm 7 \\
(10-50)\end{array}$ & 0 & $\begin{array}{c}122 \pm 36 \\
(20-250)\end{array}$ & $\begin{array}{c}34 \pm 10 \\
(10-80)\end{array}$ & $\begin{array}{c}1558 \pm 574 \\
(370-4000)\end{array}$ & $\begin{array}{c}830 \pm 207 \\
(375-2000)\end{array}$ & 0 \\
\hline $\begin{array}{l}\text { (6) Argentina, Mendozal, } \\
\text { Bardas Blancas, 1964, } 3\end{array}$ & $\begin{array}{l}\text { scarce } \\
(<5)\end{array}$ & 0 & $\begin{array}{c}171 \pm 52 \\
(65-400)\end{array}$ & $\begin{array}{c}58 \pm 7 \\
(35-80)\end{array}$ & $\begin{array}{c}2100 \pm 283 \\
(1200-3300)\end{array}$ & $\begin{array}{c}2600 \pm 433 \\
(940-4500)\end{array}$ & 0 \\
\hline $\begin{array}{l}\text { B. trifolium } \\
\text { (3:pool) Perú, Huanuco, } \\
\text { 1963, 1 }\end{array}$ & 0 & 0 & 550 & 100 & 0 & 0 & 0 \\
\hline $\begin{array}{l}\text { B. tariegatus } \\
\text { (6:pool) Argentina, Neucuuén, } \\
\text { Lacar Lake, } 1964,1\end{array}$ & 0 & 0 & 8600 & 750 & 0 & 0 & 0 \\
\hline
\end{tabular}

10 , not detectable $(<1-2 \mu \mathrm{g} / \mathrm{g})$.

Figure 1 gives a synopsis of the different indolealkylamines found in the skin of Bufonids and indicates the enzyme systems involved in their biosynthesis.

The presence in skin extracts of indole acids or indole alcohols as metabolites of indolealkylamines is of no importance in the present study, since they are simply indicative of the activity of monoamineoxidase, an enzyme of widespread distribution in vertebrates.

It is obvious that the occurrence in the skin of a given amine signifies the obligatory occurrence of the enzymes interfering in its production. For example, occurrence of 5-HT implies the successive activity of the enzyme couple tryptophan 5-hydroxylase and 5-hydroxytryptophan decarboxylase; occurrence of $\mathrm{O}$-methylbufotenine 1-sulphonic acid the activity of the considerably more complex enzyme set tryptophan-5-hydroxylase +5 -hydroxytryptophan decarboxylase $+N$-methyl transferase +5 -hydroxyindole- $O$-methyl transferase + sulphoconjugase.

Thus, designating an amine is the same thing as designating a peculiar enzyme set, and vice versa. 
TABLE 5. THE CONTENT OF INDOLEALKYLAMINES IN THE SKIN OF TOADS (IN $\mu \mathrm{G}$ FREE BASES PER G TISSUE). ${ }^{1}$

\begin{tabular}{|c|c|c|c|c|c|c|c|}
\hline $\begin{array}{c}\text { Taxa, sample size, } \\
\text { locality, date }\end{array}$ & $5-\mathrm{HT}$ & $\begin{array}{c}\text { N-Methyl- } \\
\text { 5-HT }\end{array}$ & Bufotenine & Bufotenidine & $\begin{array}{c}\text { Dehydro- } \\
\text { bufotenine }\end{array}$ & Bufothionine & Bufoviridine \\
\hline \multicolumn{8}{|l|}{$\begin{array}{l}\text { "North-Eastern line" } \\
\text { americanus group }\end{array}$} \\
\hline $\begin{array}{l}\text { B. terrestris } \\
\text { (4:pool) USA, Florida, } \\
\text { Gainesville, 1966, } 6\end{array}$ & 1600 & $68-80$ & 20 & 1300 & $20-30$ & 0 & 0 \\
\hline \multicolumn{8}{|l|}{ woodhousei group } \\
\hline $\begin{array}{l}\text { B. woodhousei woodhousei } \\
\text { (2) USA, Texas, Austin, } \\
\text { 1964,6 } \\
\text { (9) USA, Texas, Austin, }\end{array}$ & $500-800$ & 40 & 0 & $950-1200$ & $150-200$ & 0 & 0 \\
\hline 1965,6 & $\begin{array}{c}302 \pm 58 \\
(100-600)\end{array}$ & $\begin{array}{l}50 \pm 11 \\
(20-100)\end{array}$ & 0 & $\begin{array}{c}306 \pm 55 \\
(70-600)\end{array}$ & $\begin{array}{l}27 \pm 6 \\
(7-55)\end{array}$ & 0 & 0 \\
\hline $\begin{array}{l}\text { B. woodhousei australis } \\
\text { (8) USA, Arizona, Mesa, } \\
\text { 1964,9 }\end{array}$ & $\begin{array}{l}1081 \pm 158 \\
(550-2000)\end{array}$ & $\begin{array}{c}154 \pm 30 \\
(80-300)\end{array}$ & $?$ & $\begin{array}{c}1469 \pm 323 \\
(500-3000)\end{array}$ & $\mathbf{0}$ & 0 & 0 \\
\hline $\begin{array}{l}\text { B. microscaphus } \\
\text { (2:pool) USA, Utah, } \\
\text { 1966,6 }\end{array}$ & 600 & 160 & 60 & 5200 & 0 & 0 & 0 \\
\hline hemiophrys group & & & & & & & \\
\hline $\begin{array}{l}\text { B. hemiophrys } \\
\text { (7) USA, Dakota, Forks, } \\
1965,6\end{array}$ & $\begin{array}{c}317 \pm 82 \\
(10-600)\end{array}$ & $\begin{array}{c}96 \pm 26 \\
(20-170)\end{array}$ & $\begin{array}{c}68 \pm 22 \\
(10-180)\end{array}$ & $\begin{array}{c}676 \div 144 \\
(270-1200)\end{array}$ & $\begin{array}{l}1993+806 \\
(250-6000)\end{array}$ & 0 & 0 \\
\hline
\end{tabular}

${ }^{1} 0$, not detectable $(<\mathrm{l}-2 \mu \mathrm{g} / \mathrm{g})$.

II

The application of our non-morphological line of evidence permits the establishment of some general criteria of affinity between different species or groups of toads, which may be of great utility for a "biological" definition of the evolutionary trends of these species or groups. It is obvious, however, that our biochemical data must be considered in parallel with, and supported by, other kinds of evidence, such as genetic compatibility, call structure, morphology, etc.

The tabulated data show that every group of toads possesses a fairly peculiar and constant spectrum of indoealkylamines and, consequently, a peculiar set of enzymes, responsible for their biosynthesis.

The African regularis stock contains in its skin only 5-HT together with at least two conjugates of the amine, and hence probably only tryptophan 5-hydroxylase, aromatic L-amino acid decarboxylase and one or more conjugates (Table 1). Bufo melanostictus, on the contrary, of the "southoriental line," possesses a considerably more complete spectrum of amines, indicating the occurrence in its skin also of enzymes catalyzing the cyclisation of bufotenine and of a highly active $N$-methyltransferase, as shown by the enormous amounts of bufotenidine. In the "Paleartic line" a distinction appears evident between a bufo group and a calamita group, the former with a skin rich in dehydrobufotenine and bufothionine, the latter with a skin lacking, or containing negligible amounts of, cyclised indolealkylamines, but presenting high concentrations of the rather uncommon $O$ sulphate of bufotenine, bufoviridine.

The boreas, punctatus, alvarius, debilis and spinulosus groups (Tables 2, 3 and 4) are all characterized by lack or scarcity of 5-HT in their skin, in the presence of varying amounts of bufotenine. Whereas bufotenidine may be detected only in the borcas and spinulosus groups, dehydrobufotenine and/or bufothionine are present in the skin of nearly all groups. 
TABLE 6. THE CONTENT OF INDOLEALKYLAMINES OF THE SKIN OF TOADS (IN $\mu \mathrm{G}$ FREE BASES PER G TISSUE). ${ }^{1}$

\begin{tabular}{|c|c|c|c|c|c|c|c|}
\hline $\begin{array}{c}\text { Taxa, sample size, } \\
\text { locality, date }\end{array}$ & 5-HT & $\begin{array}{l}\text { N-Methyl- } \\
\text { 5-HT }\end{array}$ & Bufotenine & Bufotenidine & $\begin{array}{l}\text { Dehydro- } \\
\text { bufotenine }\end{array}$ & Bufothionine & Bufoviridine \\
\hline "Southern line" & & & & & & & \\
\hline marinus group & & & & & & & \\
\hline $\begin{array}{l}\text { B. marinus marinus } \\
\text { (7) Nicaragua, 1964, } 9\end{array}$ & $\begin{array}{l}554 \pm 117 \\
(50-1600)\end{array}$ & $\begin{array}{l}353 \pm 149 \\
(25-1200)\end{array}$ & $\begin{array}{c}? \\
\text { ( } 30 \text { in one } \\
\text { pecimen only) }\end{array}$ & 0 & $\begin{array}{c}3743 \pm 652 \\
(1500-6000)\end{array}$ & $?$ & 0 \\
\hline $\begin{array}{l}\text { (4:pool) Costa Rica, } \\
\text { S. José, 1962, } 5 \\
\text { (12-males:pool) Surinam, }\end{array}$ & 100 & 50 & 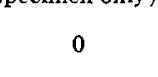 & 0 & 2200 & 320 & 0 \\
\hline & 100 & 130 & 4 & 0 & 3000 & 465 & 0 \\
\hline $\begin{array}{l}\text { Paramaribo, 1960, } 5 \\
\text { (6:pool) Surinam, }\end{array}$ & 30 & 40 & 3 & 0 & 2700 & 430 & 0 \\
\hline Paramaribo, 1962, 4 & 140 & 100 & 0 & 0 & 6000 & 30 & 0 \\
\hline $\begin{array}{l}\text { B. marinus horribilis } \\
\text { (2:pool) México, Veracruz, } \\
1963,10\end{array}$ & 500 & 300 & 30 & 25 & 3000 & 40 & 0 \\
\hline $\begin{array}{l}\text { B. narinus poeppigi } \\
\text { (1) Ecuador, Machala, } \\
\text { 1965, } 1 \\
\text { (8) Perú, Tumbez, 1965, } 1\end{array}$ & $\begin{array}{c}400 \\
577 \pm 120 \\
(220-1300)\end{array}$ & $\begin{array}{c}250 \\
342 \pm 56 \\
(180-650)\end{array}$ & $\begin{array}{l}0 \\
0\end{array}$ & $\begin{array}{l}0 \\
0\end{array}$ & $\begin{array}{c}140 \\
535 \pm 36 \\
(290-750)\end{array}$ & 10 & 0 \\
\hline $\begin{array}{l}\text { (3:pool) Perú, } \\
\text { Huacabamba, 1965, } 1 \\
\text { (5:pool) Perú, Huanuco, }\end{array}$ & 970 & 380 & 0 & 0 & 330 & 32 & 0 \\
\hline & 160 & 100 & 0 & 0 & 270 & 300 & $\mathbf{0}$ \\
\hline Yungas, 1963,1 & 165 & 150 & 0 & 0 & 1100 & 300 & 0 \\
\hline $\begin{array}{l}\text { B. ictericus } \\
\text { (pool) Brazil, Rio de Janeiro }\end{array}$ & o & 20 & 0 & 0 & 4500 & 310 & 0 \\
\hline $\begin{array}{l}\text { (poo) BrazI, Sao Paulo, } \\
\text { (F) (MET) } \\
\text { (7:pool) Argentina, }\end{array}$ & 3.5 & 4 & 3 & 0 & 1800 & 45 & 0 \\
\hline Misiones, Oberá, 1962,10 & 60 & 50 & 15 & 0 & 3300 & 465 & 0 \\
\hline $\begin{array}{l}\text { B. paracnemis } \\
\text { (8:pool) Argentina, } \\
\text { Formosa, 1960,4 } \\
\text { (8:pool) Argentina, }\end{array}$ & 70 & 80 & 4300 & 180 & 180 & 360 & 0 \\
\hline $\begin{array}{c}\text { Tucumán, 1960, } 1 \\
\text { (2:pool) Argentina, } \\
\text { Corrientes, Paraná }\end{array}$ & 25 & 0 & 2800 & 220 & 120 & 140 & 0 \\
\hline $\begin{array}{c}\text { River, 1961, } 2 \\
\text { (5:pool) Argentina, }\end{array}$ & 15 & 0 & 5000 & 650 & 250 & 370 & 0 \\
\hline $\begin{array}{l}\text { Corrientes, Iberá, 1961, } 2 \\
\text { (11:pool) Argentina, }\end{array}$ & 35 & 0 & 4500 & 400 & 270 & 370 & 0 \\
\hline $\begin{array}{l}\text { Misiones, El Dorado, } \\
1961,2\end{array}$ & 100 & 200 & 2500 & 250 & 1500 & 450 & 0 \\
\hline $\begin{array}{l}\text { B. arenarum } \\
\text { (13) Argentina, Mendoza, } \\
\text { 1965, } 6 \\
\text { (260:several pools) }\end{array}$ & $\begin{array}{r}145 \pm 20 \\
(40-300)\end{array}$ & $\begin{array}{c}80 \pm 10 \\
(35-160)\end{array}$ & $\begin{array}{c}604 \pm 58 \\
(270-900)\end{array}$ & $\begin{array}{c}55 \pm 6 \\
(20-100)\end{array}$ & $\begin{array}{c}286 \pm 50 \\
(75-715)\end{array}$ & $\begin{array}{c}254 \pm 39 \\
(60-600)\end{array}$ & 0 \\
\hline $\begin{array}{l}\text { Argentina, Cordoba, } \\
\text { Tucumán, } 1960\end{array}$ & $40-250$ & $40-200$ & $800-2600$ & $20-130$ & $250-700$ & $190-560$ & 0 \\
\hline
\end{tabular}

10 , not detectable ( $<1-2 \mu \mathrm{g} / \mathrm{g}$ ); (F), fresh skin; MET, methanol extraction.

A peculiar characteristic of the alvarius, punctatus, debilis and spinulosus groups is the frequent occurrence in their skin of bufoviridine and/or bufotenine $O$-sulphate. This characteristic strongly supports Blair's point of view on the existence of some ancient interrelations between a calamita- ancestor and boreas and related groups of the so-called "northern line." Similarly, a remarkable affinity between the punctatus-marmoreus-perplexus stock and the peculiar alvarius can be here stressed, again in accordance with Blair's assumption that considers this isolated, giant form 
Table 7. The content of INDOLEalkylamines of the SKin of toads (IN $\mu \mathrm{G}$ FREE BASES PER G TISSUE).

\begin{tabular}{|c|c|c|c|c|c|c|c|}
\hline $\begin{array}{l}\text { Taxa, sample size, } \\
\text { locality, date }\end{array}$ & 5-HT & $\begin{array}{c}\text { N-Methyl- } \\
5-\mathrm{HT}\end{array}$ & Bufotenine & Bufotenidine & $\begin{array}{l}\text { Dehydro- } \\
\text { bufotenine }\end{array}$ & Bufothionine & Bufoviridine \\
\hline \multicolumn{8}{|l|}{ "Southern line" } \\
\hline \multicolumn{8}{|l|}{ granttlostus group } \\
\hline \multicolumn{8}{|l|}{$\begin{array}{l}\text { B. granulosus goeldi } \\
\text { (10) Brasil, Amazonas, } \\
\text { Oriximina, 1967, I }\end{array}$} \\
\hline $\begin{array}{l}\text { B. pygmaeus } \\
\text { (11) Argentina, Santa Fé, } \\
\text { La Criolla, 1964,112 }\end{array}$ & $\begin{array}{c}52 \pm 16 \\
(5-190)\end{array}$ & $\begin{array}{c}99 \pm 19 \\
(15-200)\end{array}$ & $\begin{array}{c}92 \pm 16 \\
(25-200)\end{array}$ & 0 & $\begin{array}{l}2339 \pm 407 \\
(430-4300)\end{array}$ & $\begin{array}{c}350 \div 64 \\
(95-1000)\end{array}$ & 0 \\
\hline \multicolumn{6}{|l|}{ B. maior } & 980 & 0 \\
\hline $\begin{array}{l}\text { (10:pool) Argentina, Chaco, } \\
\text { Resistencia, 1964, 12 } \\
\text { (10:pool) Argentina, }\end{array}$ & 270 & 120 & 120 & 0 & 1000 & 940 & 0 \\
\hline Formosa, 1964, 1 & 60 & 20 & 140 & 0 & traces & 375 & 0 \\
\hline $\begin{array}{l}\text { B. fernandezae } \\
\text { (11) Argentina, Santa Fé, } \\
\text { La Criolla, 1964,112 }\end{array}$ & $\begin{array}{c}194 \pm 32 \\
(70-400)\end{array}$ & $\begin{array}{c}609 \pm 86 \\
(220-1200)\end{array}$ & $\begin{array}{l}238 \pm 46 \\
(20-500)\end{array}$ & 0 & $\begin{array}{c}2199 \pm 252 \\
(840-3600)\end{array}$ & $\begin{array}{c}1680 \pm 184 \\
(420-2750)\end{array}$ & 0 \\
\hline $\begin{array}{l}\text { (6:pool) Argentina, Chaco, } \\
\text { Resistencia, 1962, 112 } \\
\text { (3:pool) Argentina, Chaco, }\end{array}$ & 150 & 500 & 150 & 0 & 2400 & 1350 & 0 \\
\hline $\begin{array}{l}\text { Resistencia, 1964, 12 } \\
\text { (15:pool) Argentina, }\end{array}$ & 750 & 650 & 80 & $\mathbf{0}$ & 1250 & 1930 & 0 \\
\hline Buenos Aires, 1962, 8 & 60 & 350 & 150 & 0 & 1200 & 1100 & 0 \\
\hline \multicolumn{8}{|l|}{ typhonius group } \\
\hline $\begin{array}{l}\text { B. typhonius } \\
\text { (1) Panama, Darien, } \\
1963,10\end{array}$ & 10 & $?$ & 0 & 0 & 450 & 790 & 0 \\
\hline \multicolumn{8}{|l|}{ valliceps group } \\
\hline \multirow{2}{*}{$\begin{array}{l}\text { B. valliceps } \\
\text { (7:pool) USA, Texas, } \\
\text { Austin, 1963, } 8 \\
\text { (7) USA, Texas, } \\
\text { Austin, 1964, } 6\end{array}$} & 1600 & 0 & 0 & 0 & 0 & 0 & 0 \\
\hline & $\begin{array}{r}1200 \pm 140 \\
(500-1600)\end{array}$ & 0 & 0 & 0 & 0 & 0 & 0 \\
\hline \multicolumn{8}{|l|}{ cognatus group } \\
\hline $\begin{array}{l}\text { B. cognatus } \\
\text { (6) USA, Texas, } \\
\text { Austin, 1964, } 6\end{array}$ & $\begin{array}{c}133+27 \\
(50-240)\end{array}$ & 0 & 0 & 0 & ? & 0 & 0 \\
\hline $\begin{array}{l}\text { (10) USA, Texas, } \\
\text { Spearman, } 1965,6\end{array}$ & $\begin{array}{c}38 \pm 9 \\
(10-90)\end{array}$ & $\begin{array}{c}? \\
(10 \text { in one } \\
\text { specimen })\end{array}$ & $\begin{array}{c}\stackrel{?}{\text { ( } 5-10 \text { in } 5} \\
\text { specimens })\end{array}$ & 0 & $\mathbf{0}$ & 0 & $\mathbf{0}$ \\
\hline $\begin{array}{l}\text { (5) USA, Arizona, } \\
\text { Mesa, } 1964,8\end{array}$ & $\begin{array}{c}750 \pm 246 \\
(200-1600)\end{array}$ & $\begin{array}{l}48 \pm 25 \\
(5-140)\end{array}$ & 0 & 0 & $\begin{array}{l}26 \pm 11 \\
(7-75)\end{array}$ & 0 & 0 \\
\hline $\begin{array}{l}\text { (10) USA, Arizona, } \\
\text { Portal, 1965, } 7\end{array}$ & $\begin{array}{c}213 \pm 48 \\
(10-460)\end{array}$ & $\begin{array}{c}64 \pm 13 \\
(5-180)\end{array}$ & 0 & 0 & $\begin{array}{c}91 \pm 27 \\
(6-260)\end{array}$ & 0 & 0 \\
\hline $\begin{array}{l}\text { (1) México, Durango, } \\
1963,11\end{array}$ & 600 & 20 & 0 & 0 & 10 & $\mathbf{0}$ & 0 \\
\hline \multirow{2}{*}{$\begin{array}{l}\text { B. sueciosus } \\
\text { (1) USA, Texas, Cotulla, } \\
\text { 1963, II } \\
\text { (12) USA, Texas, Austin, } \\
\text { 1964, 5-6 }\end{array}$} & 650 & 90 & 0 & 0 & 50 & 0 & 0 \\
\hline & $\begin{array}{c}2079 \pm 351 \\
(300-4500)\end{array}$ & $\begin{array}{c}274 \pm 34 \\
(50-450)\end{array}$ & 0 & 0 & $\begin{array}{l}98 \pm 26 \\
(30-290)\end{array}$ & 0 & 0 \\
\hline \multicolumn{8}{|l|}{ canaliferus group } \\
\hline $\begin{array}{l}\text { B. canaliferus } \\
\text { (1) México, Chiapas, } \\
\text { 1963, I1 } \\
\text { (4:pool) Guatemala, 1966, }\end{array}$ & $\begin{array}{l}3000 \\
5000\end{array}$ & $\begin{array}{l}120 \\
150\end{array}$ & $\begin{array}{l}0 \\
0\end{array}$ & $\begin{array}{c}80 \\
0\end{array}$ & $\begin{array}{l}0 \\
0\end{array}$ & $\begin{array}{l}250 \\
375\end{array}$ & $\begin{array}{l}0 \\
0\end{array}$ \\
\hline
\end{tabular}


TABle 7. Continued.

\begin{tabular}{|c|c|c|c|c|c|c|c|}
\hline $\begin{array}{l}\text { Taxa, sample size, } \\
\text { locality, date }\end{array}$ & 5-HT & $\begin{array}{c}\text { N-Methyl- } \\
\text { 5-HT }\end{array}$ & Bufotenine & Bufotenidine & $\begin{array}{l}\text { Dehydro- } \\
\text { bufotenine }\end{array}$ & Bufothionine & Bufoviridine \\
\hline \multicolumn{8}{|l|}{ coccifer group } \\
\hline $\begin{array}{l}\text { B. coccifer } \\
\text { (12:pool) San Salvador, } \\
\text { S. Vicente, } 1964,9\end{array}$ & 120 & 10 & 0 & 1450 & 0 & 0 & 0 \\
\hline \multicolumn{8}{|l|}{ incertae sedis groups } \\
\hline $\begin{array}{l}\text { B. luetkeni } \\
\text { (4) Nicaragua, 1964, } 11\end{array}$ & $\begin{array}{c}405 \pm 162 \\
(130-800)\end{array}$ & $\begin{array}{c}20 \pm 1 \\
(8-30)\end{array}$ & $\begin{array}{l}42 \pm 14 \\
(12-75)\end{array}$ & $\mathbf{0}$ & 0 & 0 & 0 \\
\hline $\begin{array}{l}\text { B. haematiticus } \\
\text { (12:pool) Costa Rica, } \\
\text { Turrialba, 1964, } 8\end{array}$ & 2100 & 0 & 0 & 0 & 9000 & 0 & 0 \\
\hline
\end{tabular}

to be a derivative of the above stock. The high degree of specialization of alvarius is, on the other hand, confirmed by the formidable 5 -hydroxyindole $O$-methyl transferase activity of its skin, leading to the accumulation in the cutaneous glands of enormous amounts of 5-methoxyindolealkylamines. In this regard, $B$. alvarius occupies an unique position among all the Bufonidae considered here.

Another interesting result of our screening in the spinulosus group is the demonstration of a diverging amine spectrum in B. trifolium Tschudi, often considered merely a subspecific unit in the spinulosus complex. B. trifolium, like B. variegatus from the extreme southern forest of Chile, lacks the enzyme system(s) leading to the cyclisation of bufotenine to dehydrobufotenine. Thus, our biochemical data are decidedly in favour of the validity of Bufo trifolium Tschudi.

The spectrum of indolealkylamines in the americanus stock of the "northern line" shows (Table 5) some correspondence with the hypothetical differentiation proposed by Blair between an eastern, long-calling group of species (americanus, terrestris, houstonensis), a western group of shortcalling forms (hemiophrys) and a group (woodhousei) of presumed earliest speciation. Occurrence of some dehydrobufotenine in woodhousei from Texas, but apparently not in woodhousei from Arizona, may be a significant difference, supporting the validity of Bufo woodhousei australis
Shannon and Lowe, formerly based on morphology alone.

The arrangement of the "southern line" on the basis of our biochemical data may be once again favourably compared with the generalization by Blair. A neotropical marinus group may be recognized. The marinus populations from Mexico to Bolivia show a wide similarity in the spectrum of biogenic amines, although a lesser content of dehydrobufotenine in marinus poeppigi than in marinus marinus and marinus horribilis is clearly evident. Whereas Bufo ictericus is quite similar to marinus populations, $B$. paracnemis shows a reduced content of dehydrobufotenine accompanied by a considerable concentration of bufotenine and bufotenidine, practically absent in the other marinus-like species, except arenarum. The species of the granulosus group and similarly of the typhonius group, can be considered somewhat related to the larger species of the marinus group. A moderate $N$-methyltransferase activity, never attaining to the formation of bufotenidine, and a remarkable activity of cyclizing enzymes and of sulphoconjugase are the most important characteristics of their enzyme spectrum.

In the Bufo valliceps and Bufo cognatus groups, the exclusive or largely predominant indolealkylamine is 5-HT, as in the African toads. $N$-methyltransferase is moderately active in speciosus and in Mexican and Arizonan populations of cognatus, but apparently is much less active in cognatus 
Table 8. The CONTENT OF INDOLEalkylamines IN THE SKin of Melanophryniscus (IN $\mu \mathrm{G}$ FREE BASES PER G TISSUE).

\begin{tabular}{|c|c|c|c|c|}
\hline $\begin{array}{c}\text { Taxa, sample size, } \\
\text { locality, date }\end{array}$ & $5-\mathrm{HT}$ & N-Methyl-5-HT & Bufotenine & $\begin{array}{l}\text { Other } \\
\text { indolealkylamines }\end{array}$ \\
\hline $\begin{array}{l}\text { Melanophryniscus moreirae } \\
\text { (1900:pool) Brazil, Guanabara, 1962, } 12 \\
\text { (1290:pool) Brazil, Guanabara, 1964, } 1\end{array}$ & $\begin{array}{l}25 \\
30\end{array}$ & $\begin{array}{l}22 \\
37\end{array}$ & $\begin{array}{l}3700 \\
2600\end{array}$ & $\begin{array}{l}0 \\
0\end{array}$ \\
\hline $\begin{array}{l}\text { Melanophryniscus stelzneri atroluteus } \\
\quad(8: \text { pool) Uruguay, } 1966,3 \text { (F) }\end{array}$ & 0 & 0 & 0 & 0 \\
\hline $\begin{array}{l}\text { Melanophryniscus stelzneri stelzneri } \\
\quad \text { (7:pool) Argentina, San Luis Sierras, 1964, II }\end{array}$ & 0 & 0 & $5(?)$ & 0 \\
\hline
\end{tabular}

10 , not detectable ( $<1-2 \mu \mathrm{g} / \mathrm{g})$; (F), fresh skin.

from Texas. Finally, B. canaliferus and $B$. coccifer are almost similar in their content of bufotenidine, while diverging in their content of bufothionine.

The position of Melanophryniscus as an independent offshoot of some ancient South American bufonid stock has been of interest since Griffith's revision (1959). Although data herein reported may be considered conclusive only for Melanophryniscus moreirae, they seem to support Griffith's conclusions. In fact, the above species presented in its skin, together with small amounts of 5-HT and N-methyl-5-HT, enormous amounts of bufotenine, indicating an intense $N$-methyltransferase activity, similar to that found in a number of toads. On the other hand the strict taxonomic relationships between $M$. stelzneri stelzneri and $M$. stelzneri atroluteus is strikingly stressed by our findings.

It may be seen from the preceding anal$y$ sis and discussion that demonstration and comparison of the specific amine spectra, considered as phenotypic expressions of genetically determined enzyme activity, may substantially support ideas concerning the limits existing among the different species groups of toads. However, at a higher level of phyletic relationships, far back in the evolutionary history of the past and in the present lines of the genus Bufo, evidence provided by a critical analysis of our biochemical screening must be applied cautiously. Only a reasonably complete agreement between amine screening and evidence from many other morphological, embryological and ecological sources could offer an adequately solid basis for the most generalized reconstructions, such as the ancient separation of the "northern" and "southern" lines in accord with the existence of actual Asiatic counterparts of these two lines, and prior to the arrival of the genus into North America in the Oligocene. On the other hand, the possibility of a Neotropical origin of some of these stocks is now strongly discussed, as a result in part of the recent interpretation of the Patagonian oligocenic fossil, Neoprocoela, as a bufonid-like form (cf. Tihen, 1962), and in part the previous suggestions by Griffith on paedomorphic trends in bufonids as compared with other families such as the Leptodactylidae or Hylidae.

Without entering then into a detailed discussion concerning the reconstruction of the evolutionary history and the late diversification of the actual lines of toads, we believe it may be useful to put forward an adaptation of the arrangement by Blair (1963), modified in agreement with the data of our present screening. Figure 2 clearly shows that there is virtually no conflict between our present arrangement and Blair's implications. Two major phyletic lines can be supported, but the punctatus-marmoreus-perplexus group fits better into the general pattern of the "northern line." Such an assemblage can be stressed also by the presence of bufoviridine, both in punctatus and debilis groups and in calamita forms from Europe. An earlier segregation of americanus and boreas stocks could be probably postulated, and a new "south-western line" related to the "north- 


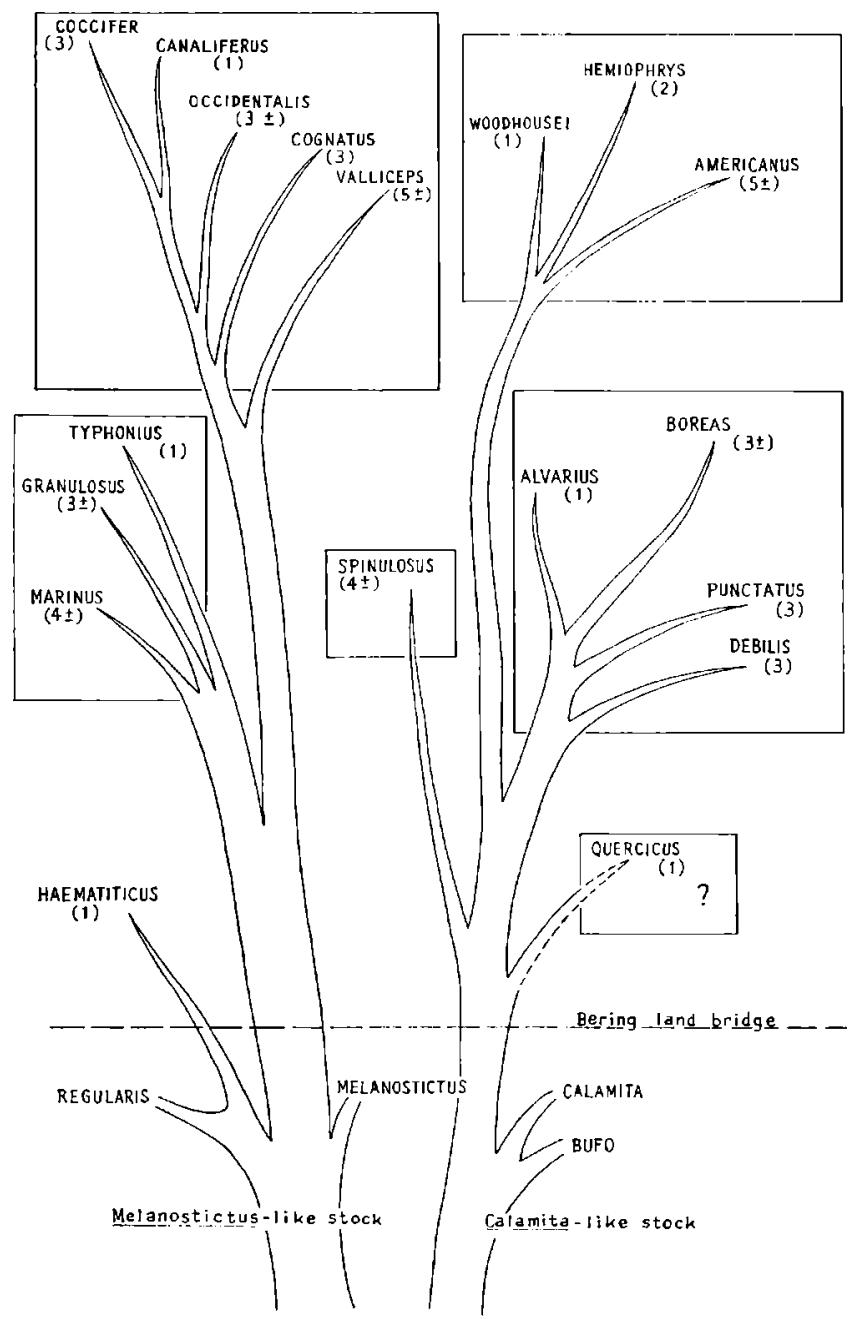

FIG. 2.-Tentative phylogenetic arrangement of the species groups of American toads (genus Bufo) as in the previous arrangement by Blair and taking into account the present biochemical evidence.

western line" should be also introduced for the spinulosus group, in full agreement with the experimental evidence given by Blair (1964) and our serological results by precipitin tests (Cei and Cohen, 1965).

In the "southern line" a granulosus and a typhonius group were added to marinus as nearby, related stocks. The species groups valliceps, cognatus, coccifer and canaliferus fall unaltered, as in Blair's arrangement (1966). Specimens of the occidentalis group were not available for our screening.
The oldest phyletic relationships between the ancestors of the "southern line" and haematiticus and regularis stocks may be probably suggested (cf. Table 7). Tihen (1962), on the other hand, pointed out the problematic relationships of the isolated, monotypic haematiticus group from Costa Rica, both for its valliceps-like features and for some resemblances to the African species. We should like to quote here a passage from Tihen, discussing a hypothetical origin of his "americanus group": “. . . it 
could have developed from the same sort of ancestral stock that has been postulated to have given rise to both the haematiticus and valliceps groups. . .." Thus, it is interesting to observe another of the frequent examples of convergence arising from assumptions of the most independent lines of research.

\section{SUMMARY}

Results of a widespread screening on the content of indolealkylamines in the skin of 48 bufonid forms permits a generalized analysis of the limits of most species groups according to their presumed evolutionary history and the most recent studies of speciation. The comparison of the specific amine spectra in the skin, considered as phenotypic expressions of genetically-regulated enzyme activity, supports the existence of two main lines of continental evolution of the genus $B$ ufo in nearctic and neotropical America, as previously postulated by Blair. The presence of bufoviridine in the punctatus and debilis groups is strong biochemical evidence in favour of a probable relationship between a boreas-like "northern line" and some calamita-like ancestors. Striking similarities have been demonstrated between the "northern line" groups and the spinulosus Andean stock, in agreement with other completely independent results, arising from crossability studies and serological tests. Speciation of the americanus group, as postulated by Blair, is well supported by the relative divergence of the amine spectra in all its hitherto observed forms. Relationships between the isolated, very specialized alvarius and the punctatus-marmoreus stocks were discussed, and its position as a presumed member of the boreas stock is reinforced by our non-morphological evidence.

The existence of a "southern line" appears to be in accordance with the biochemical evolution of the enzyme systems regulating the indolealkylamine metabolism in the American toads. An early aggregation of a marinus group, with a proper active late speciation, is equally evident.
The granulosus and typhonius groups, as nearby related stocks, were added to the marinus branch in our tentative arrangement. The biochemical position of valliceps, cognatus, canaliferus and coccifer groups appears to be in full agreement with their evolutionary position as postulated in the tentative arrangement of Blair. Ancient relationships of haematiticus with the ancestors that could have given rise to valliceps group were also stressed. The analysis of populational patterns establishes the fairly constant and rigorous systematic value of the spectra of biogenic amines. Our analysis also indicates possible geographic variation in the amine content of the skin.

Consequently, the line of biological evidence pursued in the present studies may be really useful in contributing in the solution of problems of subspecific relationships and allo-sympatric speciation. Our remarks on Bufo trifolium Tschudi and on Bufo woodhousei australis Shannon and Lowe may be considered fair examples.

\section{ACKNOWLEDGMENTS}

This project was supported by grants from the Consiglio Nazionale delle Ricerche, Roma, Italy. We acknowledge the help given to our screening by Prof. W. F. Blair, University of Texas, Austin; by Dr. W. E. Duellman, Museum of Natural History, University of Kansas, Lawrence, and by Ing. V. G. Roig, Instituto de Biologia, Universidad Nacional de Cuyo, Mendoza, Argentina.

\section{REFERENCES}

BLAIR, W. F. 1963. Evolutionary relationships of North American toads of the genus Bufo: a progress report. Evolution, 17:1-16.

BLAII, W. F. 1964. Evidence bearing on relationships of the Bufo boreas group of toads. Texas J. Sci., 16:181-192.

BLAIR, W. F. 1966. Genetic compatibility in the Bufo valliceps and closely related groups of toads. Texas J. Sci., 18:333-351.

Cer, J. M., and R. Cohen, 1965. Tests photronicos y filogenia de los Bufónidos americanos. Com. Acta $\mathrm{III}^{\circ}$ Congr. Sudamer. Zool. Santiago de Chile, Octubre, 1965 (Inv. Zool. Chil.: in press). 
Cer, J. M., V. Erspamer, and M. Roseghini. 1967. Taxonomic and evolutionary significance of biogenic amines and polypeptides occurring in amphibian skin. I. Neotropical leptodactylid frogs. Syst. Zool., 16:328-342.

Erspamer, V., M. Roseghini, and A. Anastasi. 1965. Occurrence and distribution of N-acetylhistidine in brain and extracerebral tissue of poikilothermal vertebrates. J. Neurochem., 12: 123-130.

Erspamer, V., M. Roseghini, and J. M. Cei. 1964. Indole-, imidazole-, and phenyl-alkylamines in the skin of thirteen Leptodactylus species. Biochem. Pharmacol., 13:1083-1093.

Erspamer, V., T. Vitali, M. Roseghini, aNd J. M. CEI. 1964. The identification of new histamine derivatives in the skin of Leptodactylus. Arch. Biochem. Biophys., 105:620-629.

Erspamer, V., T. Vitali, M. Roseghini, and J. M. CEI. 1967. 5-Methoxy- and 5-hydroxyindoles in the skin of Bufo alvarius. Biochem. Pharmacol., 16:1149-1164.

Griffith, J. 1959. The phylogeny of Sminthillus limbatus and the status of the Brachycephalidae (Amphibia Salientia). Proc. Zool. Soc. London, $132(3)$ :457-487.
Hunsaker, D., R. E. Alston, W. F. Blatr, and B. L. Turner. 1961. A comparison of the ninhydrin positive and phenolic substances of parotoid gland secretions of certain Bufo species and their hybrids. Evolution, 15:352-359.

Porter, K. R. 1962. Evolutionary relationships of the Bufo valliceps group in Mexico. Unpub. Doctoral Dissertation, Univ. Texas.

Porter, K. R. 1964. Chromatographic comparisons of the parotoid gland secretions of six species of the Bufo valliceps group, p. 451-456. In C. A. Leone [ed.], Taxonomic biochemistry and serology. Ronald Press, New York.

Robinson, B., G. F. SMith, A. H. Jackson, D. Shaw, B. Frydman, and V. Deulofeu. 1961. Dehydrobufotenin. Proc. Chem. Soc. :310-311.

TiHEN, J. A. 1962. Osteological observations on New World toads. Amer. Midl. Nat., 67:157183.

Wittliff, J. L. 1962. Parotoid gland secretions in two species groups of toads (genus Bufo). Evolution, 16:143-153.

Instituto de Biologia, Universidad $\mathrm{Na}$ cional de Cuyo, Mendoza, Argentina, and Istituto di Farmacologia, Università di Parma, Parma, Italia. 
